\title{
City Brand Competitiveness: Exploring Structural Relationships Among City Brand Equity Elements in China
}

\author{
Kunjoon Lee \\ Graduate School of Management, Shanghai University, Shanghai, China
}

Email address:

leekunjoon@naver.com

To cite this article:

Kunjoon Lee. City Brand Competitiveness: Exploring Structural Relationships Among City Brand Equity Elements in China. International Journal of Business and Economics Research. Vol. 6, No. 3, 2017, pp. 32-39. doi: 10.11648/j.ijber.20170603.11

Received: April 10, 2017; Accepted: May 13, 2017; Published: May 16, 2017

\begin{abstract}
Majority of cities in the developing and transitional parts of the world, being a global city has turned into a primary goal. With this trend, managing a brand asset of a city has become an important task for countries, especially China. Therefore, the study explores the causality between the city brand equity factors, and clarifies the correlation between city brand identity and city brand loyalty. Survey with the size of 300 was gathered to be analyzed. Through a rigorous instrument development process, the following five construct were identified: brand awareness, brand image, perceived quality, brand identity, and brand loyalty. The instrument was proven to have a good fit, reliability, and validity. Three factors (brand awareness, brand image, perceived quality) were analyzed on how it affects brand identity and the effect of brand identity on brand loyalty. The purpose of this paper is to provide preliminary strategical data for city development and marketers in China.
\end{abstract}

Keywords: City Competitiveness, City Brand, Brand Equity, Brand Management

\section{Introduction}

Today, 54 per cent of the world's population lives in urban areas, a proportion that is expected to increase to 66 per cent by 2050 . Projections show that urbanization combined with the overall growth of the world's population could add another 2.5 billion people to urban populations by 2050, with close to 90 percent of the increase concentrated in Asia and Africa. [1] These city residents are generating more than 80 per cent of global GDP. [2] This is the highest in the history of mankind and the numbers are still growing dramatically.

Therefore, managing urban places has become one of the most important urban management challenges of the twenty-first century. Urban management in the first decade of the twenty-first century was characterized by the use of city marketing and the creation and development of city branding in order to find differentiating factors that enable cities to position themselves in the minds of their different target groups at home and abroad.

City competitiveness can thus be seen as the ability to compete on, possess and control the market in order to create value in a fast, economical manner, and to offer prosperity to its local residents. Economy, science and technology, as well as international influence are all vital driving force for stronger city competitiveness. [3] Brand assets of different cities may be comprised of common elements. However, each asset of a city brand at a comprehensive level is unique, and this uniqueness becomes a critical managerial subject. [4] It has also been mentioned, by Doel and Hubbard, that competitive advantage arises from the strategic manipulation of local assets, and that the internal characteristics of a city are fundamental to the city's competitiveness and success. [5]

In parallel with the competition for stronger brand powers among cities, the importance of effective brand management for cities is increasing. However, only limited numbers of studies have depicted urban competitiveness in transitional economies such as China [6], and seems that China's urbanization and their rapidly changing status are need to be understood with diverse perspective.

Therefore, this research has limited its periphery to Chinese cities. It is reasonable to assume that China will be one of the countries experiencing the most extreme urbanization for the decades ahead. Levels of urbanization vary greatly across regions and Asia remains mostly rural, with 48 per cent of its populations living in urban areas. McKinsey estimates that, by 2030, the towns and cities of the 
developing world will make up 81 percent of urban humanity [7] As of 2014, China has the largest urban population in the world, reaching up to 758 million urban dwellers, accounting for 20 per cent of the global total. [1]

Many of the previous studies have considered brand identity as the core of the development progress. Cai [8], Kaplanidou and Vogt [9], Konecnik and Go [10], and Konecnik and de Chernatony [11] have developed various theoretical frameworks to study the concept of brand identity, however no consensus has been reached. Therefore, Tsaur, Yen, and Yan [12] have suggested a scale for place brand identity from a customer based perspective and redefined the elements of brand identity more suitable for place branding. This research also follows this customer based perspective and develops the model further by defining the relationship between brand equity factors and brand loyalty which is suggested by Aaker [13] as one of the core element of brand equity.

Furthermore, as noted by Lever and Turok [14], cities do not compete in the same way that companies do, with profit maximization as the most important objective. Cities instead compete for residents, tourist, funding, event, investments, etc. However, many of the city brand research have focused on the tourism aspect only. This research takes into account both internal and external perspectives of brand creation [15] and focused on the consumption of a city brand in general covering residents, tourists, and businesses.

\section{Literature Review}

\subsection{Research on City Brands in China}

There is an extensive amount of literature on urban development in China [16]. For example, scholars that have focused on research areas relating to city branding in a Chinese setting have studied the connection between globalization and urban development; place promotion and city image [17] [18] [19], place-making and the planning process of brands in Chinese cities [20] [21].

\subsection{The Conceptual Framework}

\subsubsection{Brand Awareness}

Aaker defines awareness as the strength of a brand's presence in the consumer's mind. [22] Keller explains that awareness goes through both brand recognition and recall. There are many levels considering brand awareness. These levels range from brand recognition, to brand recall, to top of mind, to brand dominance, to brand knowledge, and to brand opinion. [23] As one moves from brand recognition to brand opinion, the brand awareness increases. [22] When a destination wants to be successful, it must first achieve tourist awareness and second a positive image [24]

Keller suggests three roles of brand awareness in consumer decision making. [23]

1) It is important that consumers think of the brand when they think about the product category

2) Brand awareness can affect decisions about brands in the consideration set, even if there are essentially no other brand associations.

3) It affects consumer decision making by influencing the formation and strength of brand associations in the brand image

It can be said that most models of consumer behavior argues that awareness is a first and necessary. However, brand awareness will not always lead to purchase, because it results, at best, in product curiosity. [25]

H1: Brand awareness has a direct effect on brand identity in consuming a city brand.

\subsubsection{Brand Image}

City image has been studied since 1950s, and Boulding was the first person to define city image. He defined it as 'a comprehensive outcome of subjective minds and experiences'. [26]

Kevin Lynch, in his book 'The image of the city', states that the contents of city images which are related to physical forms, can conveniently be classified into five types of elements: paths edges, districts, nodes, and landmarks. Even though his analysis conducted limited itself to the effects of physical, perceptible objects, it well explains the mechanism of city image. He explains that the image was not a precise, miniaturized model of reality, reduced in scale and consistently abstracted. As a purposive simplification, it was made by reducing, eliminating, or even adding elements to reality, by fusion and distortion, by relating and structuring the parts. It was sufficient, perhaps better for its purpose if rearranged, distorted, or even 'illogical'. However distorted, there was a strong element of topological invariance with respect to reality. [27]

More recently, Kotler defined place image as a series of belies that a person of a group of people have towards that area, in order to show the place in a more preferable way. These series of beliefs imply that the character of a product can be explained by the sum of consumer's assessments. [28] [29]

In overall, sum of consumer's assessments through experience on a place leads to a belief and this creates image of that place.

H2: Brand image has a direct effect on brand identity in consuming a city brand.

\subsubsection{Perceived Quality}

Quality is a consumer's subjective opinion on the extent to which particular product or service will meet his expectations. [13] It therefore is about consumer's judgement about a product's overall excellence or superiority. [30]

Gill and Dawra explains that it is important consumers perceives a brand to be high at its quality, since it will directly relate to the brand preference and increase brand equity pie. [31]

In reviewing the past studies related to destination development, only a few were found covering the topic of perceived quality. This is interesting because the tourist's overall evaluation of a destination is a combination of products, services, and experiences. In all these examples, 
quality is a vital element affecting consumer behavior [32].

The research was designed to infuse the above-mentioned perspectives. In this study, quality is represented by how people feel and judge that a brand is of the best quality and is consistent with quality.

H3: Perceived quality has a direct effect on brand identity in consuming a city brand.

\subsubsection{Brand Identity}

Brand identity is created by organizations and reflects the contribution of all brand elements to image and awareness. [33] Brand identity also provides a direction or meaning to the brand and is central to a brand's strategic vision. [22] Also, it differentiates the brand from its competitors and signifies what the organization will and can do over time. [34]

Taking the frame of brand identity onto cities, it can largely be explained in two aspects, conformity and individuality. Conformity is about changes and continuity. Regardless of the changes that are happening in the city, people think that 'there is something constant about this city'. As the time goes, people will identify themselves to this continuity and think 'this city and I have are alike' or 'my character fits this city well'. On the other hand, there is individuality. Individuality is about when people find the city unique and superior in a way. Therefore, people are more likely to think that 'this city is special and better than other cities'. [35]

Moreover, the identity of a city brand is about being distinguishable from other cities. It is stretched from the city's unique appearance and characters. Thus, it is not only about the past but also about the process itself. [36]

In this research, the questions were designed to measure how people identity to the city characters and see how people distinguish one city from another.

H4: Brand identity has a direct effect on brand loyalty in consuming a city brand.

\subsubsection{Brand Loyalty}

Aaker defines brand loyalty as "attachment that a customer has to a brand". [13] Another definition is by Oliver, that brand loyalty is "an attained state of enduring preference to the point of determined defense". [37] Mellens cited the definition of brand loyalty as "the biased behavioral response expressed over time by some decision making unit with respect to one or more alternative brands out of a set of such brands and is a function of psychological process. [38]

The concept of brand loyalty has been extensively studied in the marketing literature. Keller operationalized brand loyalty as the main source of customer-based brand equity. [39] Opperman argued that loyalty should not be neglected when examining destination brands. [40] However, in terms of measurement, a review of the literature highlights the lack of clarity about the conceptual nature of brand loyalty. This has resulted in the use of a variety of measurement tools producing inconsistent findings [41]. As Gill and Dawra has incorporated in their research, this paper follows the definition which consist both the behavioral and attitudinal dimensions. [31] Behavioral loyalty means that there is repeated purchase by the consumers, which can be translated as repeated visit in this paper. Attitudinal loyalty means the attitude, beliefs, and intentions of the consumer towards the brand, such as feelings.

H5-1: Brand identity mediates the effect between brand awareness and brand loyalty

H5-2: Brand identity mediates the effect between brand image and brand loyalty

H5-3: Brand identity mediates the effect between perceived quality and brand loyalty

\section{Analysis}

\subsection{Methodology}

Since the major purpose of this research is to clarify the relationships between brand equity factors in consumers' perceptions towards Chinese cities, a self-structured questionnaire was developed to collect the required primary data from the visitors and residents. The questionnaire is designed to contain five main distinct sections, each of which consisted relevant questions pertaining different parts of the study. Questionnaires were made in Chinese and English version and were distributed on both online and offline.

In order to list the Chinese cities for the survey, top ten cities has been chosen according to the 'Chinese cities' brand power index 2015 (中国城市品牌力指数)". This is an annual report by Tsinghua University research center for nation brand which measures the brand power of cities in China. The selected cities were Beijing, Shanghai, Guangzhou, Chengdu, Chongqing, Wuhan, Nanjing, Hangzhou, and Tianjin.

Initially, 30 items were rewritten to produce an original questionnaire. The wordings of all items were designed with the meanings of each brand equity concept. Respondents indicated their agreement with each item, using a five-point Likert-type scale ranging from five (strongly agree) to on (strongly disagree). Several questions were included to obtain the respondents' demographic attributes and visit information. Prior to data collection, a pilot survey was conducted in order to ensure the reliability of the questionnaire. The questionnaire was distributed to 65 tourists in Shanghai. Based on the survey results, several items were revised or deleted. Finally, 23 items were selected in the final format.

Survey data were collected from 24 September 2016 to 8 October 2016. The online questionnaires were distributed through major social networking service (QQ, Wechat). The offline questionnaires samples were collected randomly from populated districts in Shanghai (Baoshan, Jing'an, and Huangpu). A total of 300 of the collected samples were found valid for analysis.

In total, 310 questionnaires were distributed and returned. After excluding cases with missing values, a total of 300 responses were retained for analysis. The participant profiles are shown in Table 1. 
Table 1. Profile of respondents.

\begin{tabular}{|c|c|c|}
\hline Variables & Description & $\mathbf{N}(\%)$ \\
\hline \multirow{2}{*}{ Nationality } & Chinese & $193(64.3)$ \\
\hline & Foreign & $107(35.7)$ \\
\hline \multirow{8}{*}{$\begin{array}{l}\text { Current } \\
\text { residence }\end{array}$} & Beijing & $11(3.7)$ \\
\hline & Shanghai & $230(76.7)$ \\
\hline & Guangzhou & $2(0.7)$ \\
\hline & Chengdu & $6(2.0)$ \\
\hline & Chongqing & $6(2.0)$ \\
\hline & Nanjing & $2(0.7)$ \\
\hline & Hangzhou & $4(1.3)$ \\
\hline & Others & $39(13.0)$ \\
\hline \multirow{2}{*}{ Gender } & Male & $96(32.0)$ \\
\hline & Female & $204(68.0)$ \\
\hline \multirow{5}{*}{ Age } & Under 20 & $27(9.0)$ \\
\hline & $20 \sim 29$ & $200(66.7)$ \\
\hline & $30 \sim 39$ & $58(19.3)$ \\
\hline & $40 \sim 49$ & $13(4.3)$ \\
\hline & More than 50 & $2(0.7)$ \\
\hline \multirow{3}{*}{ Marriage } & Single & $241(80.3)$ \\
\hline & Married & $59(19.7)$ \\
\hline & Elementary/ Secondary/High school & $14(4.7)$ \\
\hline \multirow[t]{2}{*}{ Education } & Undergraduate & $193(64.3)$ \\
\hline & Post graduate or higher & $93(31.0)$ \\
\hline \multirow{5}{*}{ Occupation } & Student & $173(57.7)$ \\
\hline & Government organization & $24(8.0)$ \\
\hline & Company employee & $65(21.7)$ \\
\hline & Self-employed & $22(7.3)$ \\
\hline & Others & $16(5.3)$ \\
\hline \multirow{6}{*}{ Income level } & Less than $\$ 600$ & $137(45.7)$ \\
\hline & $\$ 600 \sim \$ 1000$ & $48(16.0)$ \\
\hline & $\$ 1000 \sim \$ 1500$ & $41(13.7)$ \\
\hline & $\$ 1500 \sim \$ 3000$ & $45(15.0)$ \\
\hline & $\$ 3000 \sim \$ 4500$ & $14(4.7)$ \\
\hline & More than $\$ 4500$ & $15(5.0)$ \\
\hline
\end{tabular}

Table 2. Reliability analysis.

\begin{tabular}{|c|c|c|c|}
\hline Items (alpha 0.898 ) & Mean & Std. Dv. & Reliability \\
\hline \multicolumn{4}{|l|}{ Brand Awareness } \\
\hline AW1 & 4.42 & 0.816 & \multirow{6}{*}{0.867} \\
\hline AW2 & 4.47 & 0.815 & \\
\hline AW3 & 4.26 & 0.856 & \\
\hline AW4 & 4.38 & 0.904 & \\
\hline AW5 & 3.97 & 1.019 & \\
\hline AW6 & 4.00 & 1.035 & \\
\hline \multicolumn{4}{|l|}{ Brand Image } \\
\hline IM1 & 3.87 & 0.938 & \multirow{3}{*}{0.808} \\
\hline IM2 & 3.83 & 0.990 & \\
\hline IM3 & 3.83 & 0.938 & \\
\hline \multicolumn{3}{|l|}{ Perceived Quality } & \multirow{7}{*}{0.794} \\
\hline QU1 & 3.66 & 0.990 & \\
\hline QU2 & 3.59 & 1.006 & \\
\hline QU3 & 3.74 & 0.898 & \\
\hline QU4 & 3.52 & 1.033 & \\
\hline QU5 & 4.06 & 0.912 & \\
\hline QU6 & 3.54 & 1.042 & \\
\hline \multicolumn{3}{|l|}{ Brand Identity } & \multirow{6}{*}{0.821} \\
\hline ID1 & 3.89 & 0.968 & \\
\hline ID2 & 4.11 & 0.872 & \\
\hline ID3 & 3.70 & 0.934 & \\
\hline ID4 & 3.67 & 0.930 & \\
\hline ID5 & 4.16 & 0.844 & \\
\hline \multicolumn{3}{|l|}{ Brand Loyalty } & \multirow{4}{*}{0.841} \\
\hline LO1 & 4.14 & 0.808 & \\
\hline LO2 & 4.27 & 0.751 & \\
\hline LO3 & 3.96 & 0.998 & \\
\hline
\end{tabular}

Table 3. KMO and Barlett's test.

\begin{tabular}{lll}
\hline \multicolumn{2}{l}{ Kaiser-Meyer-Olkin measure of sampling adequacy } & $\mathbf{0 . 8 5 6}$ \\
\hline \multirow{3}{*}{ Bartlett's test of sphericity } & Approx. Chi-square & 3396.751 \\
& Df & 253 \\
& Sig. & 0.000 \\
\hline
\end{tabular}

\subsection{Results}

\subsubsection{Reliability Coefficient}

Reliability coefficient tested by using Cronbach's alpha analysis. In order to measure the reliability for a set of two or more constructs, Cronbach alpha is commonly used method where alpha coefficient values range between 0 and 1 with higher values indicating higher reliability among the indicators. [42] Hence, 1 is the highest value that can be achieved. According to Table 2, the total scale of reliability for this study varies from $0.794 \sim 0.867$ indicated that all factors were found to be reasonably reliable with Cronbach's alpha values of greater than 0.70 . [43] The reliability of this study is substantial in every perspective.

\subsubsection{Confirmatory Factor Analysis}

Samples from 310 respondents had been thoroughly analyzed and the outputs of the results have been clearly explained in this section. Applying SPSS, Principal Component Analysis (PCA) was carried out to explore the underlying factors associated with 23 items. The constructs validity was tested applying Barlett's Test of Sphericity and the Kaiser-Mayer-Olkin (KMO) measure of sampling adequacy analyzing the strength of association among variables. In order to verify whether the data are suitable of using factor analysis, the KMO measure of sampling adequacy was computed beforehand. KMO is used to assess which variables to drop from the model due to multicollinearity problem. The value of KMO varies from 0 to 1 , and KMO overall should be 0.60 or higher to perform factor analysis. If not achieved, it is necessary to eliminate the variables with lowest values and adjust the KMO overall. Result of the Barlett's test of sphericity and the KMO revealed that both were highly significant and eventually concluded that these variables was suitable for the factor analysis (Table 3). Deciding upon the number of factors that can be retained is difficult but initial runs- based on eigen values showed 5 factors. To determine the minimum loading necessary to include an item in its respective constructs, Hair et al. (1992) suggested that variables with loading greater than 0.30 is considered significant, loading greater than 0.40 more important, and loading 0.0 or greater are very significant. In this research, the general criteria were accepted items with loading of 0.60 or greater. Not a single factor has dropped out which means the factor analysis was a success. The result of Table 4 highlighted the amount of variance explained by these five factors $(63.386 \%)$.

The values of the following Table 5 indicate the affiliation of the items to a factor. Generally, the factor is the natural affinity of an item for a group. The higher loading factor indicates the stronger affiliation of an item to a specific factor. 
The findings of this study indicate that each of the five dimensions (brand awareness, brand image, perceived quality, brand identity, and brand loyalty) were homogeneously loaded to the different factors. This means that each of the items was successfully loaded into five different factors.

Table 4. Total variance explained.

\begin{tabular}{|c|c|c|c|c|c|c|c|c|c|}
\hline \multirow{2}{*}{ Comp. } & \multicolumn{3}{|c|}{ Initial eigenvalues } & \multicolumn{3}{|c|}{ Extraction sums of squared loadings } & \multicolumn{3}{|c|}{ Extraction sums of rotated squared loadings } \\
\hline & Total & $\%$ of Variance & Cumulative (\%) & Total & $\%$ of Variance & Cumulative (\%) & Total & $\%$ of Variance & Cumulative (\%) \\
\hline 1 & 7.269 & 31.606 & 31.606 & 7.269 & 31.606 & 31.606 & 3.699 & 16.081 & 16.081 \\
\hline 2 & 2.883 & 12.534 & 44.140 & 2.883 & 12.534 & 44.140 & 3.062 & 13.315 & 29.396 \\
\hline 3 & 1.783 & 7.752 & 51.892 & 1.783 & 7.752 & 51.892 & 2.987 & 12.987 & 42.383 \\
\hline 4 & 1.453 & 6.317 & 58.208 & 1.453 & 6.317 & 58.208 & 2.453 & 10.664 & 53.047 \\
\hline 5 & 1.191 & 5.177 & 63.386 & 1.191 & 5.177 & 63.386 & 2.378 & 10.339 & 63.386 \\
\hline 7 & .853 & 3.711 & 71.598 & & & & & & \\
\hline 8 & .730 & 3.174 & 74.772 & & & & & & \\
\hline 9 & .611 & 2.656 & 77.427 & & & & & & \\
\hline 10 & .582 & 2.531 & 79.958 & & & & & & \\
\hline 11 & .569 & 2.474 & 82.433 & & & & & & \\
\hline 12 & .528 & 2.295 & 84.728 & & & & & & \\
\hline 13 & .504 & 2.190 & 86.918 & & & & & & \\
\hline 15 & .419 & 1.820 & 90.733 & & & & & & \\
\hline 16 & .390 & 1.694 & 92.427 & & & & & & \\
\hline 17 & .317 & 1.379 & 93.806 & & & & & & \\
\hline 18 & .305 & 1.327 & 95.133 & & & & & & \\
\hline 19 & .274 & 1.191 & 96.323 & & & & & & \\
\hline 20 & .246 & 1.069 & 97.393 & & & & & & \\
\hline 21 & .245 & 1.066 & 98.458 & & & & & & \\
\hline 22 & .194 & .845 & 99.303 & & & & & & \\
\hline 23 & .160 & .697 & 100.000 & & & & & & \\
\hline
\end{tabular}

\subsubsection{Validity, Reliability, and Invariance Test}

Before analyzing the variable model, the validity and reliability of the constructs must be calculated in advance. Uni-dimensionality measures must also be established before their convergent and discriminant validity are assessed. [44] Uni-dimensionality measures the extent to which the items in a scale all measure the same construct. [45] Confirmatory Factor Analysis (CFA) can be used to assess uni-dimensionality. A CFA was conducted for each of the five factors to determine whether the 23 indicators measured the construct they were assigned adequately. The SEM program AMOS 18.0 was used throughout the study to conduct the analyses. Empirical evidence in CFA (and SEM in general) is generally assessed using criteria such as the CMIN/DF (minimum discrepancy/degrees of freedom), RMR (root mean square residual), RMSEA (root mean square error of approximation), GFI (the goodness of fit index), and CFI (comparative fit index).

The structural equational model (SEM) was examined to test the relationship among the constructed model using AMOS 18.0. The statistical results show $\mathrm{CMIN} / \mathrm{DF}=2.001$, $\mathrm{RMR}=0.05, \mathrm{GFI} \fallingdotseq 0.90$ (0.89), CFI $=0.934$, HI $90=$ 0.923 , RMSEA $=0.058$ (Tale 6 ). It has been verified that the model has a good fit.

\subsection{Hypothesis Testing}

Figure 1 depicts the full model of the four paths hypothesized in the model; all the paths were significant at $\mathrm{p}$ $<0.05$. Every hypothesisses, except H1, showed great significance at $\mathrm{p}<0.00$.

First, it is accepted that brand awareness directly effects brand identity when consuming a city brand. H1 is accepted with the percentage of $p=0.019$. However, it is shown that this factor had comparatively less effect than other two factors affecting brand identity. Still, it is fair to say that high brand awareness leads to stronger brand identity when consuming a city brand.

The statistical findings also revealed that brand image has a direct effect on brand identity when consuming a city brand. $\mathrm{H} 2$ is accepted at $\mathrm{p}<0.00$. Positive brand image of a city can lead to a stronger brand identity.

Regarding $\mathrm{H} 3$, perceived quality has a direct effect on brand identity in consuming a city brand. H3 is also accepted at $p<0.00$. Experience of a city can lead to building a stronger brand identity of a city.

H4 was accepted at $\mathrm{p}<0.00$. The brand identity has a direct effect on brand loyalty. Table 7 summarizes the results mentioned above from $\mathrm{H} 1$ to $\mathrm{H} 4$.

From H5-1 to H5-3 were mediated model. In order to test the significance of the mediated model, bootstrapping method was used. Table 8 shows the results. All three (H5-1, H5-2, H5-3) were accepted. The H5-3(QU-ID-LO) showed the most significance $(\mathrm{p}=0.001)$ and followed by $\mathrm{H} 5-2$, and $\mathrm{H} 5-1$ in the order of significance. 
Table 5. Factor loading matrices.

\begin{tabular}{|c|c|c|c|c|c|}
\hline Descriptions & F1 & F2 & F3 & F4 & F5 \\
\hline $\begin{array}{l}\text { Awareness } \\
\text { AW1 } \\
\text { AW2 } \\
\text { AW3 } \\
\text { AW4 } \\
\text { AW5 } \\
\text { AW6 } \\
\text { Image } \\
\text { IM1 } \\
\text { IM2 } \\
\text { IM3 } \\
\text { Quality } \\
\text { QU1 } \\
\text { QU2 } \\
\text { QU3 } \\
\text { QU4 } \\
\text { QU5 } \\
\text { QU6 } \\
\text { Loyalty } \\
\text { LO1 } \\
\text { LO2 } \\
\text { LO3 } \\
\text { Identity } \\
\text { ID1 } \\
\text { ID2 } \\
\text { ID3 } \\
\text { ID4 } \\
\text { ID5 }\end{array}$ & $\begin{array}{l}.787 \\
.767 \\
.707 \\
.823 \\
.747 \\
.711\end{array}$ & $\begin{array}{l}.596 \\
.668 \\
.659 \\
.656 \\
.635 \\
.684\end{array}$ & $\begin{array}{l}.743 \\
.570 \\
.713 \\
.772 \\
.621\end{array}$ & $\begin{array}{l}.767 \\
.782 \\
.665\end{array}$ & $\begin{array}{l}.674 \\
.814 \\
.830\end{array}$ \\
\hline
\end{tabular}

Extraction method: principal component analysis.

Based on five- factors specification.

Rotation method: Varimax with Kaiser Normalization.

Loadings that are 0.50 or less are not shown

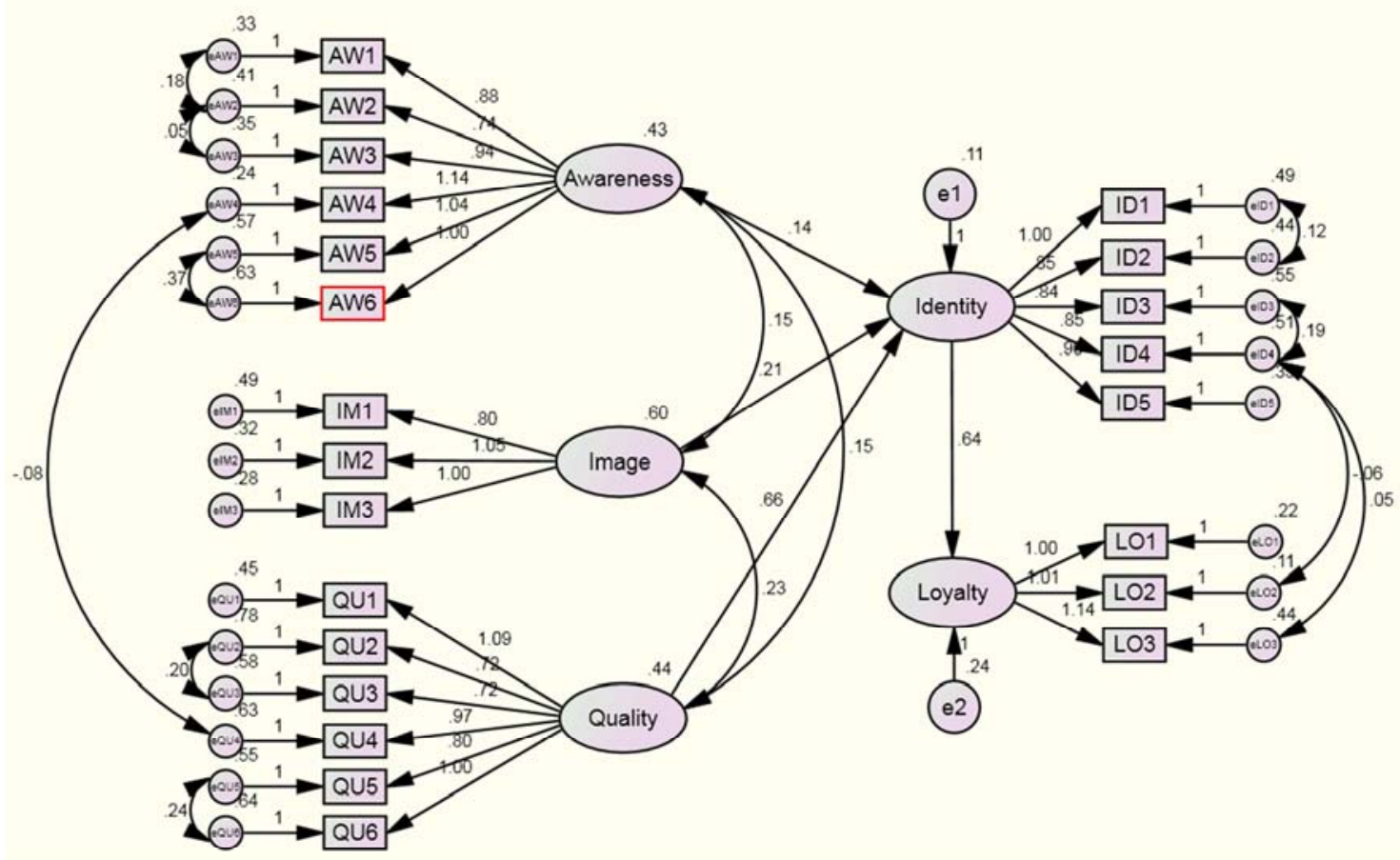

Figure 1. Degree of relationship between awareness $(A W)$, image (IM), quality $(Q U)$, identity (ID), and loyalty (LO). 
Table 6. Fit measures.

\begin{tabular}{ll}
\hline Fit measures & Main model \\
\hline CMIN/DF & 2.001 \\
RMR & 0.05 \\
GFI & $\fallingdotseq 0.90(0.89)$ \\
CFI & 0.934 \\
HI 90 & 0.923 \\
RMSEA & 0.058 \\
\hline
\end{tabular}

Table 7. Standard estimation of the main model.

\begin{tabular}{llllll}
\hline \multicolumn{2}{l}{ Standardized regression weight } & Estimate & S.E. & C.R. & P \\
\hline H1 & Awareness $(\mathrm{AW}) \rightarrow$ Identity & .138 & .060 & 2.345 & .019 \\
H2 & Image (IM) $\rightarrow$ Identity & .659 & .093 & 7.117 & $* * *$ \\
H3 & Quality (QU) $\rightarrow$ Identity & .245 & .056 & 3.807 & $* * *$ \\
H4 & Identity (ID) $\rightarrow$ Loyalty & .656 & .075 & 8.617 & $* * *$ \\
\hline
\end{tabular}

Table 8. Standard estimation of the mediated model.

\begin{tabular}{llll}
\hline Standardized regression weight & Estimate & P \\
\hline H5-1 & Awareness $(\mathrm{AW}) \rightarrow$ Identity $\rightarrow$ Loyalty & .140 & .021 \\
$\mathrm{H} 5-2$ & Image $(\mathrm{IM}) \rightarrow$ Identity $\rightarrow$ Loyalty & .212 & .009 \\
$\mathrm{H} 5-3$ & Quality $(\mathrm{QU}) \rightarrow$ Identity $\rightarrow$ Loyalty & .660 & .001 \\
\hline
\end{tabular}

\section{Conclusion}

A city's brand is increasingly considered as an important asset for urban development and an effective tool for cities to distinguish themselves and set marketing strategies aiming to generate revenue from tourism and secure investment, as well as attract qualified workers. This research aimed to reveal the relationship between brand equity factors of Chinese cities and find implications for the potential marketing strategies.

The result of this study provides several implications. Firstly, from the previous literatures on brand equity, five factors were selected. Within the brand equity factors, brand awareness, brand image, and perceived quality were chosen as the factors which affect brand identity. The level of influence among the three brand equity factors was greatest in the order of brand image, perceived quality, and brand awareness. Higher brand awareness, brand image, and perceived quality will lead to building a stronger brand identity. However, within the brand equity factors, it is possible to conclude that brand identity is mostly affected by the image and least by the recognition of a city. City brand marketers should provide consistent effort to enhance the experience that one person receives in terms of a city. Thus, not only tangible assets but also intangible assets, such as brand image, are crucial when developing a strong brand identity.

Secondly, the study reveals the effect of brand identity on brand loyalty. It is possible to conclude that possessing a strong brand identity will strengthen loyalty of residents, travelers, and businesses regarding a specific city. Both familiarity of a city and individuality to a city is creating better condition for higher brand loyalty to a city.

Lastly, a mediating role of brand identity between awareness, image, quality and loyalty has been tested. All three variables showed significance affecting brand loyalty. This test has implied that among three variables, perceived quality showed the most significance affecting brand loyalty mediated by brand identity. Considering the fact that brand image was the most significant factor affecting brand identity, the results conclude that the decisive factor which eventually leads to brand loyalty is perceived quality of a brand.

This research had several limitations. The offline survey was conducted only in Shanghai. Even though online survey was distributed nationwide, the resultant measurement scale is limited. Moreover, 35 percent of the respondents were Non-Chinese, whom were from different countries and spoke various languages. The questionnaires were provided in two languages age: simplified Chinese and English. The respondents language skills varied and may had insufficient understanding of the questions provided.

In addition, for future research, further exploratory research needs to be conducted to establish other factors that build brand equity, and the interrelationships between brand equity factors need to be studies in detail.

\section{References}

[1] United Nations Department of Economic and Social Affairs/Population Division, World Urbanization Prospects: The 2014 Revision, 2014, pp. 21

[2] UN-Habitat The World Cities Report, Urbanization and Development: Emerging Futures, 2016

[3] Jiang and Shen, 'Measuring the Urban Competitiveness of Chinese cities in 2000, Cities, 27, 307-314

[4] Soon-Hwa An, A Study On The Effect of City Brand Personality on Relationship Quality and Loyalty, 2008

[5] M. Doel and P. Hubbard, 'Taking World Cities Literally: Marketing The City In A Global Space Of Flows', 2002, City, 6(3), 351-368)

[6] Jiang Y. and Shen J., Measuring The Urban Competitiveness Of Chinese Cities In 2000, 2010, Cities, 27, pp.307-314

[7] McKinsey Global Institute, Urban World: Mapping The Economic Power of Cities, 2011, pp5-6.

[8] Cai, A., Cooperative Branding For Rural Destinations, Annals of Tourism Research, 2002, 29(3), pp. 720-742.

[9] Kaplanidou K., \& Vogt C., Destination branding: Concepts and Measurement. Working paper, Michigan State University, Department of Park, Recreation and Tourism Resources, 2003.

[10] Konecnik M. and Go F., Tourism destination brand identity: The case of Slovenia, Journal of Brand Management, 2008, 15(3), pp. 177-189

[11] Konecnik M., \& de Chernatony L., Developing and applying a place brand identity model: The case of Slovenia, Journal of Business Research, 2013, 66(1), pp.45-52.

[12] Tsaur S. H., Yen C. H., \& Yan Y. T., Destination brand identity: scale development and validation, Asia Pacific Journal of Tourism Research, 2016, 21(12), pp.1310-1323. 
[13] Aaker, D. A., Managing Brand Equity, New York, NY: Free Press, 1991.

[14] Lever W. F. and Turok I., Competitive Cities: Introduction to the Review, Urban Studies, 1999, Vol. 36, Nos 5-6, pp.791-793.

[15] Park O. J., Cai L. A. and Lehto X. Y., Bridgin Tourism Theory and Practice: Chapter 6 Collaborative Destination Branding, Emerald Group Publishing Limited, 2009, Volume 1, pp.75-86

[16] Xu, J. and Yeh, A, City repositioning and competitiveness building in regional development: new development strategies in Guangzhou, International Journal of Urban and Regional Research, 2005, 29, pp. 283-308.

[17] Wu F., Place Promotion in Shanghai, PRC, Cities, 2000, 17(5), pp. $349-361$

[18] Wu F., Globalization, place promotion and urban development in Shanghai, Journal of Urban Affairs, 2003, 25(1), pp.55-78

[19] Zhu H., Qian J., and Gao Y., Globalization and the production of city image Guangzhou's metro station advertisements, 2011, Cities, 28(3), pp. 221-229.

[20] Friedman, J, Reflections on place and place-making in the cities of China, International Journal of Urban Regional Research, 2007, 31(2), pp. 257-279.

[21] Karvelyte, K. and Chiu J-H, Planning process of city brands: a case study of Taipei city, Place Branding and Public Diplomacy, 2011, 7(4), pp. 257-270.

[22] Aaker, D. A, Measuring brand equity across products and markets, California Management Review, 1996, 38(3), pp. 102-120.

[23] Keller, K. L., Conceptualizing, measuring and managing customer-based brand equity, Journal of marketing, 1993, 57(1), pp. 1-14.

[24] Milman, A., and A. Pizam, The role of awareness and familiarity with a destination: The central Florida case. Journal of travel research, 1995, 33(3), pp. 21-27.

[25] Fesenmaierm D., C. Vogt, and Stewart, Investigating the influence of welcome center information on travel behavior. Journal of travel research, 1993, 32(3), pp. 47-51.

[26] Boulding, K. E., The Image: Knowledge in Life and Society, Ahn Arbor, MI : University of Michigan Press, 1956, pp. 1-18

[27] Kevin Lynch, The Image of the City, The MIT Press, Vol.11, 1960.

[28] Kotler, P., Principles of marketing, Prentice- Hall, 1986.

[29] Kotler, P., Analysis Planning. Implementation and Control. Marketing management, 1988.

[30] Zeithaml, V. A., Consumer perceptions of price, quality, and value: A means-end model and synthesis of evidence, Journal of Marketing, Vol. 52, No. 3, 1988, pp 3
[31] Gill M. S. \& Dawra J., Evaluating Aaker's sources of brand equity and the mediating role of brand image, Journal of targeting, Measurement and Analysis for marketing, 2010, Vol $18,3 / 4,189-198$.

[32] Konecnik M., \& Gartner W. C., Customer-based brand equity for a destination, Annals of Tourism Research, 2007 Vol. 34 No2, pp 400-421.

[33] Keller K. L., Strategic brand management: Building, measuring, and managing brand equity, Upper Saddle River, NJ: Prentice Hall, 1998.

[34] Wagner O., Peters M., and Schukert M, Internal branding in tourism destinations: The need for future research. Proceedings of the $4^{\text {th }}$ World Conference for Graduate Research in tourism, Hospitality and Leisure, Antalya, Turkey, 2008, pp. 470-486.

[35] Yoo B. L., \& Hwang K. W., Research on developing city culture environment, Seoul, Korea Arts \& Culture Education Service, 1992.

[36] Chris Murray, Marketing sense of place: New approach to place marketing. Bournes Green, England. Comedia Publications, 2001.

[37] Oliver R. L., Whence consumer loyalty? Journal of Marketing, 1999, 63, pp.33-44.

[38] Mellens, M., Dekimpe, M. G. and Steenkamp, E. M., A review of brand-loyalty measures in marketing. Tijdschrigt voor Economie en Management, 1996, XLI (4): 07-553.

[39] Keller K. L., Brand Synthesis: The Multidimensionality of Brand Knowledge, Journal of Consumer Research, 2003, 29(4), pp.595-600

[40] Opperman, M, Tourism Destination Loyalty. Journal of Travel Research, 2000, 39, pp. 78-84.

[41] Odin Y., Odin N., and Valette-Florence P., Conceptual and operational aspect of brand loyalty: an empirical investigation, Journal of Business research, 2001, Vol. 53, Issue 2, pp. 75-84.

[42] Hair J. F., Anderson R. E., Tatham R. L., Black W. C., Multivariate Data Analysis, Macmillan: New York, 1992.

[43] Bagozzi, R. P., \& Yi, Y., On the evaluation of structural equation models. Journal of the Academy of marketing science, 1988, 16(1), pp. 74-94.

[44] Anderson JC, Gerbing RV, "Some methods for repecifying measurement models to obtain unidimensional construct measurement", 1982, Journal of Marketing Research., 19(4), pp. $453-460$.

[45] Venkatraman N., "Strategic orientation of business enterprises: the construct, dimensionality and measurement", Management Science. 1989, 35(8), pp. 942-962. 